\title{
Reform of Classroom Teaching In Colleges and Universities under the Background of School-Enterprise Cooperation
}

\author{
Hua Zhao
}

\author{
Shandong Xiehe University, Shandong, Jinan, 250000, China
}

Keywords: School-enterprise cooperation; higher education; teaching reform; personnel training.

\begin{abstract}
School-enterprise cooperation is the main ways to improve the quality of talents in Colleges and universities. The purpose of this paper is to improve the practical application ability of college graduates by studying the problems between the current situation of higher education classroom teaching and social needs. Under the background of school-enterprise cooperation, we can improve the ability of combining theory with practice by changing teaching methods and adopting different teaching methods. The innovation is to enhance learning interest by task driven approach and apply theory to practice. It provides a reference for colleges and universities to train talents in the context of school enterprise cooperation under the new situation.
\end{abstract}

\section{Introduction}

The ultimate goal of training talents in Colleges and universities is to meet the needs of the society and export talents to the society. However, according to the current market research situation, the number of college graduates in China has been increasing continuously in recent years, the employment situation is grim, and the employment rate of professional counterparts is not satisfactory. However, it is also very difficult for enterprises to find suitable personnel, and there is a clear contradiction between the school and enterprise.

\section{Analysis of University Graduates}

In recent years, with the improvement of people's awareness of education and the expansion of University enrollment, the number of people receiving higher education throughout the country has shown a continuous growth trend. Data show that the number of people taking the National College Entrance Examination in 2018 reached 9.75 million, the highest since 2010; in 2018, the number of college graduates reached 8.2 million, a record high, an increase of 7.06 million compared with 2001, an increase of 1.6 million compared with 2010. Since 2011, the number of college graduates has been on the rise. Specific data are shown in Table 1-1:

Table 1 The number of college graduates in 2011-2018

\begin{tabular}{cccc}
\hline Particular year & $\begin{array}{c}\text { Number of } \\
\text { graduates }(\mathrm{M})\end{array}$ & increment(M) & $\begin{array}{c}\text { Increase the } \\
\text { percentage(\%) }\end{array}$ \\
\hline 2011 & 6.60 & ------ & ----- \\
2012 & 6.80 & 0.20 & 3.03 \\
2013 & 6.99 & 0.19 & 2.79 \\
2014 & 7.27 & 0.28 & 1.51 \\
2015 & 7.49 & 0.22 & 4.01 \\
2016 & 7.65 & 0.16 & 2.14 \\
2017 & 7.95 & 0.30 & 3.92 \\
2018 & 8.20 & 0.25 & 3.15 \\
\hline
\end{tabular}

The number of graduates from 2011 to 2018 is shown in Fig.1. 


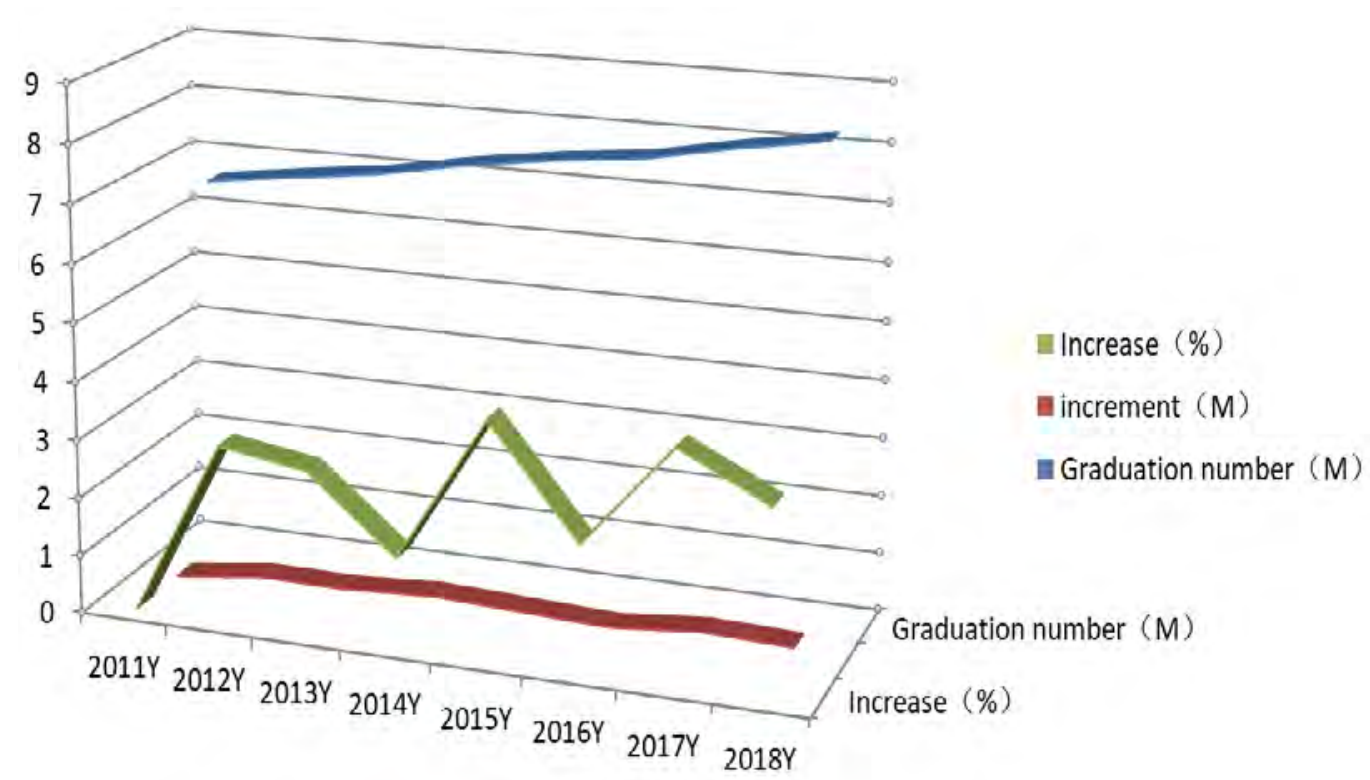

Fig. 12011 - 2018 the trend of the number of graduates in China

Through the analysis of the survey data in recent years, it is found that the total number of graduates in China has been rising since 2011, but through the survey of some enterprises, it is found that the professional counterpart rate of fresh graduates has been declining continuously. 39.2\% of the new graduates who have signed up indicate that the posts they signed up for are not in line with their major in school. This phenomenon reflects the continuing decrease in the impact of majors on employment in university campuses. This shows that there are still obvious structural contradictions between the specialty settings of Chinese universities and the market demand for employment.

\section{Analysis of Problems between College Classroom Teaching and Enterprise Needs - Taking Logistics Management as an Example}

\subsection{Differences between enterprise needs and personnel training in Colleges and Universities.}

At present, there is a serious disconnect between teaching and social practice in the major colleges and universities in China. The interaction between educational institutions and industries is insufficient, the most real industrial situation can't be understood, and some college teachers are affected by the evaluation mechanism. They do not have a deep understanding of the current situation of the industry, which is superficial and embodied in teaching. That is, there is theory without practice, in such a state of teaching students in practice and application level can be imagined. However, in the choice of employees, the enterprises focus on the practical ability of employees, continuous learning ability, independent problem solving ability, application and innovation ability. Most colleges and universities still adopt output-oriented teaching in personnel training, that is, what teachers say, what students learn, until graduation, it is found that the knowledge learned can't be directly applied to enterprises. College students' actual application ability is insufficient, the consequence is: every year there are a large number of graduates output, but the enterprise still can't find satisfactory, can be directly on the job of employees. Take logistics management as an example, every year there are a large number of logistics graduates, but for enterprises, the annual recruitment of logistics management graduates before training, it is difficult to directly post, post for the operation of the various departments of the enterprise process, the operation of various types of equipment, not to mention what will be learned. Theory has been applied to practice. There is a big problem in connection between the demand of enterprises and the talents trained in Colleges and universities.

\subsection{Enterprise needs analysis}

At present, enterprises pay more attention to the selection of Applied Talents in terms of employment, and their employment needs are mainly reflected in the following aspects: 
First, professional ethics: Professional ethics is one of the most important qualities in selecting talents. More and more companies first look at professional ethics in selecting talents, and make it the basic principle of selecting talents. If a person has no professional ethics, then he is like a time bomb in the enterprise, at any time will cause a very big threat to the enterprise. This requires colleges and universities in the training of talent, the first thing to pay attention to is the cultivation of moral quality, "talent", first become "people", and then cultivate "talent". We must not lose virtue because of "talent". Therefore, good professional ethics is the primary research point for enterprises to choose talents.

Second, professional skills: professional skills are one of the sources of competitiveness of enterprises[1]. Under the premise of guaranteeing the comprehensive ability is not bad, the specialty in a specific field will become the core competitiveness of enterprises. Therefore, colleges and universities must carry out the training of professional talents according to the characteristics of the specialty, targeted training, such as logistics specialty belongs to a new industry, involving a wide range, in mechanization, letter. The application of informationization and intellectualization is also developing rapidly. Therefore, when teaching professional knowledge, teachers should combine the frontier knowledge of the profession, constantly update their knowledge reserves, and combine theory with practice in the course of teaching, so that students can understand the frontier knowledge of the profession. In addition, in addition to theoretical courses, there are practical courses, so that students can actually operate the software and equipment used in the enterprise and similar equipment, as soon as possible familiar with the operation process of business, while under the conditions of on-site visits to the enterprise, close contact with the real industry scene. Early understanding of the actual operation of enterprises, so as to build a better bridge between schools and enterprises.

Third, learning ability: The era of knowledge economy is the era of knowledge explosion, the speed of knowledge renewal is faster and faster, college graduates in the job, the knowledge learned in the campus will gradually lag behind, in order to be competent for their own positions, we must constantly learn. Therefore, during the period of University, we should gradually develop students' ability of autonomous learning. Self-regulated learning first needs to know what knowledge they need and what are the deficiencies, and then can be targeted to search for the required knowledge materials. As an enterprise talent, only by continuous learning can enterprises and individuals maintain sustained competitiveness. Lagging knowledge and skills can only be eliminated in competition.

\subsection{Analysis of problems in classroom teaching in Colleges and Universities.}

\subsubsection{Teaching content is boring.}

As we all know, "Interest is the best teacher." Some students think that the main reason for not attending class is "lack of interest in the course," and teachers are not interested in the knowledge taught. Teaching content is the most direct knowledge system for students, directly affecting the degree of interest of students. If classroom teaching content is basically dependent on textbooks, in the long run, students will lose interest in what teachers say. Students can know what the teacher intends to say and how to say the next question by reading a book. The boring and boring teaching content greatly reduces the interest of students, and the knowledge system is generally outdated, can't lead to cutting-edge knowledge will also affect students' interest in learning.

\subsubsection{Lack of initiative of students.}

Another reason why students can't gain in the classroom is the lack of effective interaction, passive knowledge and active knowledge absorption, the effect is different. From the current situation of most colleges and universities, teachers mainly lecture in class, many teachers only pay attention to the leading role of teachers in classroom teaching, while ignoring the dominant position of students. Basically "indoctrination" is the main teaching method, the teacher speaks, the students listen, this teaching method, resulting in a dull classroom atmosphere, and students always listen to the state, will also make its thinking ossified. This learning method is mechanical and simple, which is not conducive to arousing students' enthusiasm and initiative in learning, but also to improving students' independent thinking ability and innovative thinking ability. 


\subsubsection{Teaching methods and means are single.}

According to the survey, at present, the teaching methods in Colleges and universities are mainly multimedia teaching, some courses are supplemented by blackboard books, multimedia teaching, large amount of curriculum information, and the ability to combine graphics and text, which is its advantages, but the teaching method includes not only teachers'teaching, but also students' learning, teaching and learning are complementary. To achieve good teaching results, teachers should constantly adjust the teaching methods and means according to the content and form of the course, students should cooperate with teachers, otherwise they will do half the work and fail to achieve the desired results. Besides the commonly used teaching methods in Colleges and universities, the teaching methods include discussion and intuitive demonstration. In addition to traditional blackboard writing, some electronic audio-visual equipment and multimedia network technology can also be used.

3.3.4 Teaching effect evaluation is one-sided.

Teaching assessment has a direct impact on the importance of all aspects of the teaching process; most of the current teaching assessment is based on the final test, and ignore the usual performance of students, or in proportion distribution is still biased towards the final assessment. In addition, the final test method is single, mostly written test papers. Lack of comprehensive ability of students to test, focusing on the memory of the knowledge learned assessment, resulting in some students usually does not work hard, before the exam to carry out sudden and mechanical rote learning. The students' ability to apply is less.

\section{Countermeasures for Teaching Reform in Colleges and Universities under the Background of School Enterprise Cooperation}

Under the new situation, the development of economy and the change of social demand put forward higher demand for talents training in Colleges and universities. It is not only the knowledge and skills specialty, but also the innovation ability. Therefore, the school-enterprise cooperation mode has become a necessity. Under the background of school-enterprise cooperation, the classroom teaching in Colleges and universities must be further reformed[2].

\subsection{Innovation of teaching content.}

In the process of personnel training, teaching content plays an important role, as the saying goes, "Planting beans will harvest beans." What kind of content to choose has the most direct relationship with the future export of talent. At present, a small number of colleges and universities implement the "order-based" training, that is, the teaching content of targeted design. In addition, the apprenticeship also includes the content of teaching staff in the teaching content. Of course, the innovation of teaching content is not only a simple integration into part of the enterprise, but also the formulation of the entire syllabus to carry out a unified planning, the selection of teaching materials should be careful, preferably in the last three years of teaching materials, teaching content, teaching materials only as a reference, can't be entirely in accordance with the teaching materials to lecture, to the corresponding knowledge In order to increase the students' ability to analyze and apply the knowledge they have learned, the frontier knowledge of the major and the actual case of the enterprise are integrated into the knowledge points.

\subsection{Fostering students' learning initiative.}

Interest is the best teacher for students. Only by making students interested, can students be fully mobilized to learn initiative and enthusiasm. Students are not interested in the knowledge taught in class because they feel useless and not practical, so they are not interested in it. But students are very interested in the work after graduation. Therefore, the use of school-enterprise cooperation can directly stimulate students' interest. Taking employment as the guide, we should attach importance to the cultivation of students' interests. In the process of teaching, taking students as the foundation is the foundation to cultivate students' interest in learning. Motivation is the premise of interest, therefore, teachers should first analyze students' employment intention according to the characteristics of the curriculum, induce students' internal learning motivation, in order to stimulate students' interest in learning. So that it can feel the use of learning and learn what is needed, so as to establish interest in learning the course. 
As the main body of classroom teaching, students are the main participants in the teaching process. Only by fully mobilizing their enthusiasm for participating in the classroom and active learning, can we create a relaxed and pleasant classroom atmosphere and enhance students' interest in learning[3]. There are mainly two ways to arouse students' enthusiasm for learning. First, through collective discussion, students can be guided to make suggestions and suggestions. Group discussion can stimulate students' innovative thinking in the discussion, and students' enthusiasm for participation is also high. Two, we can draw up a reward mechanism and create a competitive atmosphere. Cooperate with the enterprise, take some problems existing in the enterprise to the classroom as a case, let the students try to solve, if they can be adopted by the enterprise, they can get part of the reward, let the students learn in the competition, experience the achievement of learning, effectively mobilize the enthusiasm of students.

\subsection{Reform of teaching methods and means.}

In the process of theoretical teaching, we will inevitably encounter a lot of obscure and difficult Abstract concepts. If the teacher directly pronounces the subject or expounds it repeatedly in plain language, it will not only not promote students' understanding of the knowledge points, but also make the classroom atmosphere boring, which is not conducive to arousing students' enthusiasm to participate in learning. Therefore, it is particularly necessary to adopt diversified teaching methods and means.

4.3.1 Adopting simulation and discussion teaching method.

One of the main characteristics of school-enterprise cooperation is to shift the focus of students' study from pure theory to theory and practice. Not only can students learn the relevant theoretical knowledge, but also enable students to have a wealth of practical experience, grasp the core requirements of the industry, and improve their overall quality. Multimedia can be used in the classroom to show students the application of industry equipment, combined with experimental courses, to the laboratory or enterprise to truly experience the use of related equipment, so that students can have a personal experience. Thus, through personal experience, to understand the characteristics of different equipment, can really grasp the advantages and disadvantages of different equipment and its scope of application, through the joint discussion, brainstorming, so that students actively into thinking, so as to truly integrate theory and practice, improve students' practical ability.

4.3.2 Task driven teaching method.

Task-driven teaching method means that in the whole teaching process, with the help of teachers, students closely around a common task activity center, driven by strong problem motivation, through the active application of learning resources, carry out independent exploration and interactive and cooperative learning, and at the same time complete the established tasks. To guide students to learn and practice[4]. Task driven teaching enables students to learn with real tasks in exploration. In this process, students will continue to achieve a sense of accomplishment, can greatly stimulate their desire for knowledge, and gradually form a benign circle of perceptual mental activities, so as to cultivate independent exploration, pioneering and enterprising self-learning ability. Let the students better understand the knowledge outside the books, and drive the students to change from theoretical and technical talents to comprehensive talents[5].

\subsection{Reform of assessment methods.}

Examination is the way to test the output effect of a teaching model. Classroom teaching has been reformed. If the examination method is not changed, the final examination will lose its due significance. Therefore, curriculum assessment is an important part of teaching. The quality of curriculum assessment is an important aspect of teaching quality, which has a direct impact on teaching quality, teaching style and style of study. Under the background of school-enterprise cooperation, the way of curriculum assessment can't be determined by the last examination. Rather, it should be integrated into the students' usual performance, into the completion of practical work, into the contribution to the enterprise, and the contribution to the enterprise should be no less than $10 \%$, or the most additional items into the assessment results. Only in this way can we better promote the reform of classroom teaching, so that the two complement each other and step into a virtuous circle. 


\section{Conclusion}

School-enterprise cooperation opens a window for the reform of classroom teaching in Colleges and universities. With the help of the strength of enterprises, theoretical knowledge learned can be integrated into practical application through task-driven and other different ways in the process of learning. It can't only deepen the mastery of theoretical knowledge learned, but also understand the actual working conditions and improve the students' abilities. Practical application ability is very helpful. Based on the background of school-enterprise cooperation, the teaching reform not only points out the development goal of classroom teaching in the future, but also enriches its teaching content. It also provides practical experience for future teaching in Colleges and universities, and points out the direction of teaching reform in Colleges and universities.

\section{Acknowledgment}

Shandong vocational education teaching reform research project: Reform and application of task driven teaching mode, Project Number: 2017617

\section{References}

[1]. Deng Hanping \& Ling Daoming. Theory of process education and practice path of College Students' nurturance education [J]. Journal of sichuan university of arts and science, 2017, (03):141-143.

[2]. Hu Shuxiang \& Wu Manyi. Theory and method of social practice education for College Students [M]. Shanghai: People's Publishing House. 2014.

[3]. Li Hongyan \& Zhao Pixi. Task driven teaching mode based on creative thinking [J]. Heilongjiang Researches on Higher Education. 2016(03): 71-74.

[4]. Shen Aifeng \& Han Xueqin. Discussion and application of "task driven" teaching mode in Vocational Education [J]. Vocational Education Forum .2016(2): 1262-127.

[5]. Wu Junqi \& Liu Meng. Research on Application of "task driven" method in University flipped classroom [J]. Modern educational technology. 2017 (07): 58-64 